\title{
Seismic Performance of Existing Building Retrofitted with VSL-Gensui Damper
}

\author{
Pudjisuryadi, P. ${ }^{*}$, Lumantarna, B. ${ }^{1}$, Hermawan, T.F. ${ }^{1}$, and Gunawan, T.T. ${ }^{1}$
}

\begin{abstract}
Buildings designed using older code should be checked against the higher demand required by newer code. In this study, performance of Building T of Petra Christian University, Surabaya, Indonesia, which was designed with older Indonesian Seismic Code (PPTGIUG 1983) is investigated. The effectiveness of VSL-Gensui Damper application is also investigated as an effort to enhance the performance of the building. Nonlinear time history analysis was conducted to analyze the building. Spectrum consistent ground acceleration generated from El Centro 18 May 1940 North-South component in accordance to current seismic code was used for analysis. The result shows that the existing building cannot resist the demand specified by current code (SNI 1726:2012) as some frame element failures are detected. The performance is greatly enhanced after installation of VSL-Gensui Dampers. Roof story drift and displacement decreased as much as $9 \%$ and $14 \%$, respectively as compared to existing building, and structural element failures were no longer observed.
\end{abstract}

Keywords: Displacement; nonlinear time history; PPTIUG 1983; story drift; VSL-Gensui Damper.

\section{Introduction}

Indonesia is located on areas prone to earthquakes because there are two main rings of earthquake passing through Indonesia which are Pacific Ring stepping over Sulawesi and Papua Islands, also Trans Asiatic that traverses Sumatra, Java, Nusa Tenggara, and Sulawesi Islands [1]. Nevertheless, there are a few areas in Indonesia where earthquake happens rarely, e.g. Surabaya. However, new earthquake source findings and development of seismology causes changes in the Indonesian seismic map. Several Indonesian seismic code updates since the oldest PMI 1970 are PPTGIUG 1983, SNI 17262002, and the latest SNI 1726:2012 [2,3]. In general, the seismic hazard risk in Indonesia becomes higher, and Surabaya city is no exception. Due to these changes, performance of buildings designed using older code should be investigated. Further, retrofit works should be conducted on deficient buildings. Among the available retrofitting methods is installation of damper devices on structures. One of such damper devices is the VSL-Gensui Damper (a wall type viscoelastic damper made from a few layers of steel and rubber with $400 \times 400 \mathrm{~mm}$ and $15 \mathrm{~mm}$ thick in dimensions, see Figure 1).

\footnotetext{
${ }^{1}$ Faculty of Civil Engineering and Planning, Civil Engineering Department, Petra Christian University, Л. Siwalankerto 121-131, Surabaya 60236, INDONESIA

* Corresponding author: pamuda@petra.ac.id
}

Note: Discussion is expected before November, $1^{\text {st }} 2018$, and will be published in the "Civil Engineering Dimension", volume 21, number 1, March 2019.

Received 29 July 2018; revised 16 August 2018; accepted 20 August 2018
The application of VSL-Gensui Damper is quite easy that it is installed on infill walls or any locations between beams of adjacent stories. It can also be assigned at the substructure or superstructure.

In this study, the effects of application of VSLGensui Damper on deficient building are investigated. Building T of Petra Christian University, Surabaya, Indonesis, which was designed with older Indonesian Seismic Code (the PPTIUG 1983 that was based on Earthquake with 200-year return period) is chosen as the research object. The current Indonesian Seismic Code (the SNI 1726:2012) specifies much higher demand where the Maximum Considered Earthquake (MCE) with 2500-year return period must be considered. The structural analysis was performed using SAP2000 software [4] and the seismic performances were measured by using FEMA 356 [5] and ACMC 2001 standards [6]. The structural performances of Building $\mathrm{T}$ both in its current state as well as after the retrofit work are presented.

\section{Seismic Demand Increase of the Considered Building}

In this section, seismic demand of the building under consideration (building T of Petra Christian University) in Surabaya city is discussed. Figure 2 presents the elastic design response spectra of PPTIUG 1983 and SNI 1726:2012 for soft soil in Surabaya city where the building is located. It can be seen that both spectra differ greatly. It should be noted that the response spectrum from PPTIUG 1983 is based on earthquake with 200 year period, while that from 
SNI 1726:2012 is based on 2/3 of earthquake with 2500-year return period, referred to as the elastic design earthquake (EDE) level. It can be seen that the elastic design response spectrum increases three times from $0.2 \mathrm{~g}$ to $0.6 \mathrm{~g}$ in the short period range. However, difference of the nominal response spectra (after introducing the ductility and over strength factors to the structure) decreases. According to the codes, for design of fully ductile frames, the elastic design response spectra are divided by factors of 4 and 8 for PPTGIUG 1983 and SNI 1726:2012, respectively. The nominal response spectra can be seen in Figure 3. Thus, it can be concluded that the existing building was designed with significantly smaller seismic forces if compared to the current standard. Investigation of seismic performance of the building is imperative.
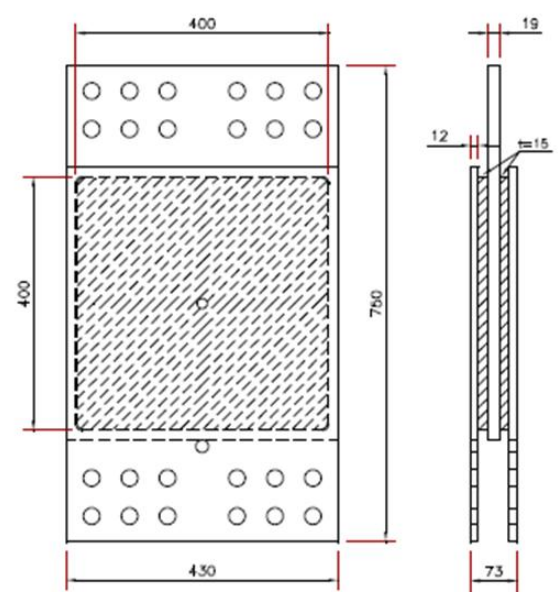

Figure 1. VSL Gensui Damper

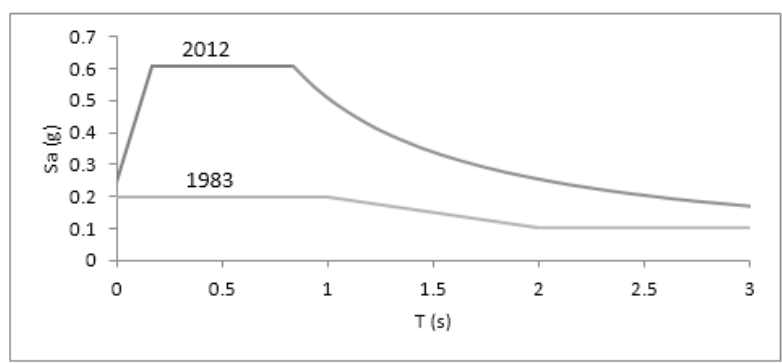

Figure 2.Elastic Design Earthquake Response Spectrum for Building T, Surabaya City, Indonesia

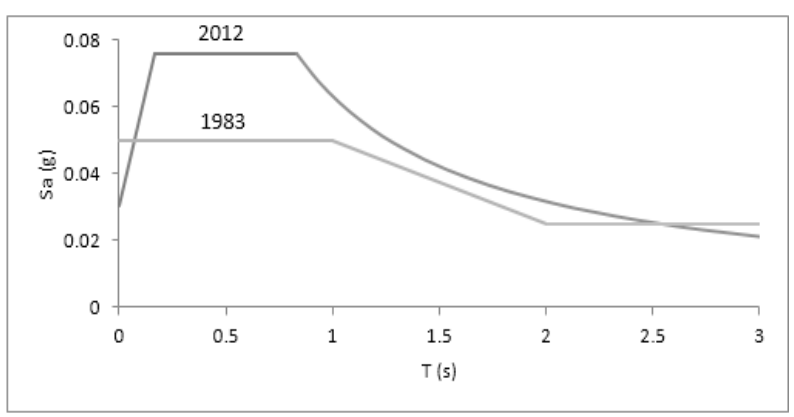

Figure 3. Nominal Earthquake Response Spectrum for Building T, Surabaya City, Indonesia

\section{Modeling of Considered Building}

This research began with modeling the existing Building T of Petra Christian University in SAP2000 software which can be seen in Figure 4. Response spectrum analysis was conducted to obtain the displacement and modal analysis was conducted to obtain the frequency of bare model (existing building, without damper). Those parameters are necessary to determine the nonlinear link property to determine the VSL-Gensui Damper properties. VSL-Gensui Damper can be assigned in SAP2000 as nonlinear link property with plastic (wen) type. There are a few parameters needed to be determined for assigning nonlinear link property which are effective stiffness, effective damping, stiffness, yield strength, and post yield stiffness ratio. There are a few equations and graphics used to obtain those five parameters [7]. After installation of VSL-Gensui dampers on the building, the analysis should be iterated to obtain the new displacement and frequency. Subsequently, it will update the values of five parameters of the VSL-Gensui damper. This iteration should be done several times until convergence with certain tolerance is obtained. It should be noted that the number and locations of VSL-Gensui damper used are determined such that a certain target performance is obtained.

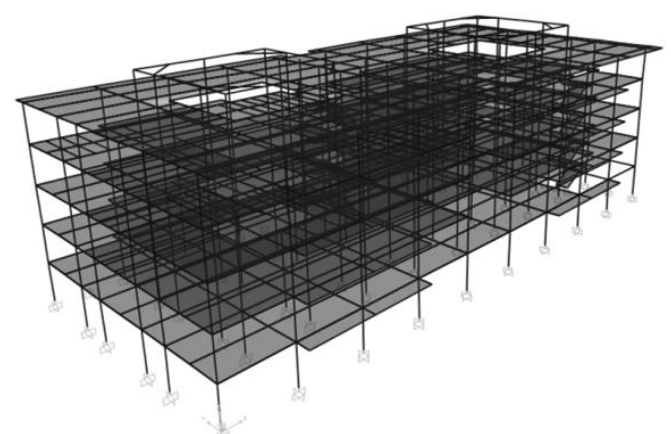

Figure 4. Modeling Building $\mathrm{T}$ of Petra Christian University

In this study, VSL-Gensui Dampers are installed as shown in Figure 5, such that failures of structural members are prevented. Damper installation locations are recommended to be symmetric on both sides of the building so that it does not move the center of rigidity of the building. In addition, the frame is safer when damper is provided up to top floor from the base [8].

Once the number and location of VSL-Gensui dampers is determined, non-linear direct integration time history analysis was conducted to analyze the building performance. CUMBIA program was used to obtain moment-curvature and force-displacement graphics which are used to model the non-linear hinge property in SAP2000 for the beams and 


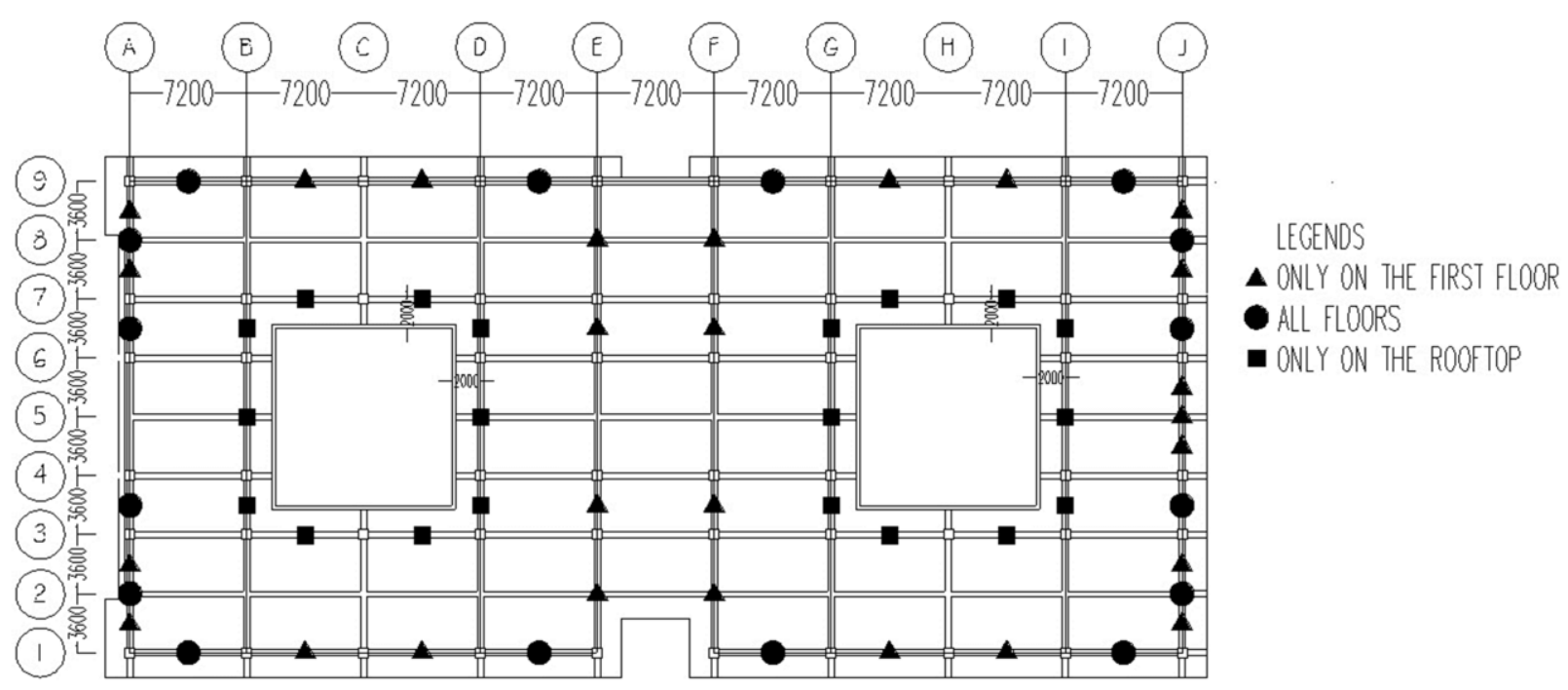

Figure 5. VSL-Gensui Damper Application Locations

columns [9]. The seismic load used was a spectrum consistent ground acceleration generated from $\mathrm{El}$ Centro 18 May 1940 North-South component in accordance to the new code (2500 year return period). The effectiveness of VSL-Gensui Damper installation can be checked from the non-linear deformations. The higher the non-linear deformation of the damper, the larger the earthquake energy absorbed by the damper.

\section{Analysis Result}

Seismic performances of the building are determined based on drift ratio and damage index of plastic hinge occurred in the structure. Earthquake performance matrix and drift ratio limits for various structural performance levels based on FEMA 356 is shown in Table 1, while damage index limits for various structural performance level based on ACMC 2001 are shown in Table 2. In Table 1 OL, IO, LS, CP present the Operational Level, Immediate Occupancy, Life Safety, and Collapse Prevention performances, respectively. While in Table 2 OP, SLS, DCLS, and S present the Serviceability Limit State, Damage Control Limit State, and Safety performances, respectively. The marks ' $v$ ' and ' $x$ ' in Tables 1 and 2 denote acceptable and unacceptable building performances respectively.

Table 1. Earthquake Performance Matrix Based on FEMA 356-2000

\begin{tabular}{|c|c|c|c|c|c|}
\hline & \multicolumn{4}{|c|}{$\begin{array}{l}\text { Target Building } \\
\text { Performance Level }\end{array}$} \\
\hline & & $\mathrm{OL}$ & $\mathrm{IO}$ & $\mathrm{LS}$ & $\mathrm{CP}$ \\
\hline \multirow{5}{*}{ 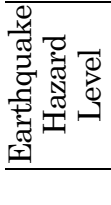 } & $50 \% / 50$ year (72 year) & $\mathrm{v}$ & $\mathrm{x}$ & $\mathrm{x}$ & $\mathrm{x}$ \\
\hline & $20 \% / 50$ year $(225$ year $)$ & $\mathrm{v}$ & $\mathrm{v}$ & $\mathrm{x}$ & $\mathrm{x}$ \\
\hline & $10 \% / 50$ year (500 year) & $\mathrm{v}$ & $\mathrm{v}$ & $\mathrm{v}$ & $\mathrm{x}$ \\
\hline & $2 \% / 50$ year (2500 year) & $\mathrm{v}$ & $\mathrm{v}$ & $\mathrm{v}$ & $\mathrm{v}$ \\
\hline & Drift Ratio & $0 \%$ & $0-1 \%$ & $1-2 \%$ & $2-4 \%$ \\
\hline
\end{tabular}

Table 2. Damage Index Limits Based on ACMC (2001)

\begin{tabular}{|c|c|c|c|c|c|}
\hline & \multicolumn{4}{|c|}{ Target Building Performance Level } \\
\hline & & $\mathrm{OP}$ & SLS & DCLS & $\mathrm{S}$ \\
\hline \multirow{3}{*}{ 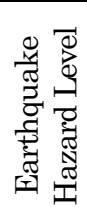 } & $\begin{array}{l}\text { Minor to } \\
\text { moderate }\end{array}$ & $\mathrm{v}$ & $\mathrm{v}$ & $\mathrm{x}$ & $\mathrm{x}$ \\
\hline & Severe & $\mathrm{v}$ & $\mathrm{v}$ & $\mathrm{v}$ & $\mathrm{x}$ \\
\hline & Ultimate & $\mathrm{v}$ & $\mathrm{v}$ & $\mathrm{v}$ & $\mathrm{v}$ \\
\hline \multicolumn{2}{|c|}{ Damage Index } & $<0.1$ & $0.1-0.25$ & $0.25-0.40$ & $0.4-1$ \\
\hline
\end{tabular}

The drift ratios of the building due to earthquake in $\mathrm{X}$ and $\mathrm{Y}$ directions are presented in Figures 6 and 7 as well as Table 3.

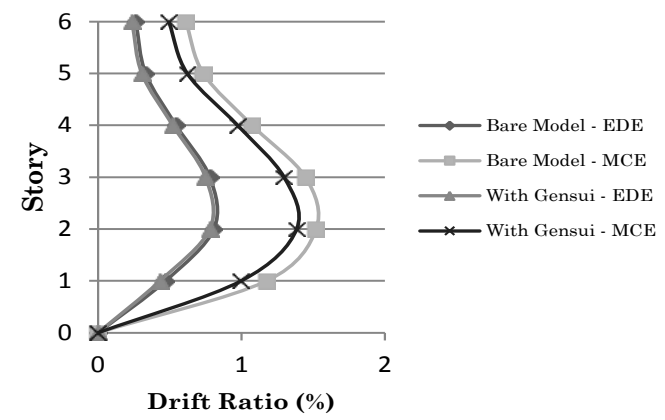

Figure 6. Drift Ratio for X Direction Earthquake

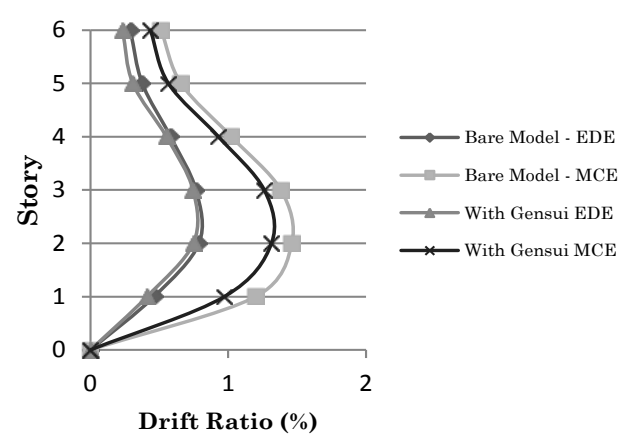

Figure 7. Drift Ratio for Y Direction Earthquake 
Table 3. Maximum Drift Ratio Reduction

\begin{tabular}{ccccc}
\hline Direction Eartqhuake & $\begin{array}{c}\text { Bare } \\
\text { Level }\end{array}$ & $\begin{array}{c}\text { With } \\
\text { Model (\%) }\end{array}$ & $\begin{array}{c}\text { Rensui (\%) } \\
\text { Reduction } \\
(\%)\end{array}$ \\
\hline X & EDE & 0.8071 & 0.7793 & 3.44 \\
& MCE & 1.5195 & 1.3844 & 8.89 \\
Y & EDE & 0.7876 & 0.7467 & 5.18 \\
& MCE & 1.4617 & 1.3142 & 10.09 \\
\hline
\end{tabular}

Typical plastic hinge location (on frame A, see Figure 5) is presented in Figures 8 and 9 to illustrate the structural damages. The summary of severity of plastic hinges in the whole building is presented in Tables 4 and 5. The seismic performance levels determined from drift ratios and damage indices of the structural component are presented in Tables 6 to 8 .

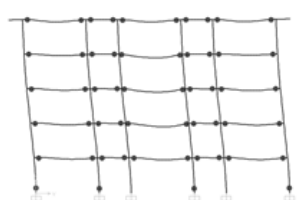

(a)

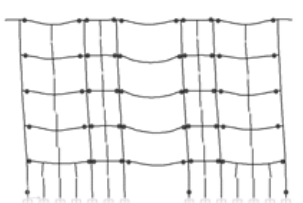

(b)
Figure 8. Frame A Plastic Hinges due to EDE (a) Bare Model; (b) With Gensui Damper

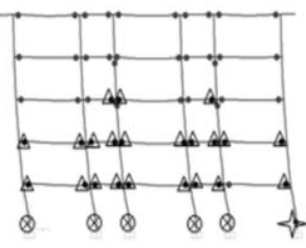

(a)

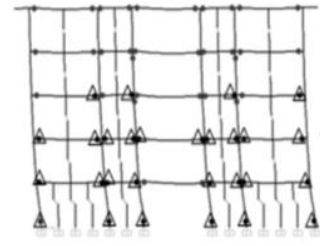

(b)
Figure 9. Frame A Plastic Hinges due to MCE (a) Bare Model; (b) With Gensui Damper

In its existing condition, both drift ratio and beam damage index of the structure (see Tables 6 and 7) are still acceptable (Tables 1 and 2). However, the column damage index (see Table 8) exceeds the specified limit. With application of VSL Gensui damper, both drift ratios and displacements are reduced. The severity of the structural member damages also decreases (see Tables 4 and 5). Building $\mathrm{T}$ of Petra Christian University, in its current condition does not survived the maximum considered earthquake (2500 years return period) as some columns collapse. However, after installation of VSL Gensui damper, the columns survive with some damage (damage index range of 0.10-0.4).

Table 4. Plastic Hinge Amount Reduction due to X Direction Earthquake

\begin{tabular}{lccccccc}
\hline EarthquakeLevel & A-B & OL & SLS & DCLS & S & $>$ C & Total \\
Damage Index & 0 & $0-0.1$ & $0.1-0.25$ & $0.25-0.4$ & $0.4-1$ & 1 & \\
\hline Bare Model - EDE & 612 & 472 & 0 & 0 & 0 & 0 & 1084 \\
With Gensui - EDE & 617 & 467 & 0 & 0 & 0 & 0 & 1084 \\
\hline Reduction (\%) & & 1.06 & 0 & 0 & 0 & 0 & \\
\hline Bare Model-MCE & 533 & 298 & 202 & 47 & 1 & 3 & 1084 \\
With Gensui-MCE & 533 & 339 & 212 & 0 & 0 & 0 & 1084 \\
\hline Reduction (\%) & & - & - & 100 & 100 & 100 & \\
\hline
\end{tabular}

Table 5. Plastic Hinge Amount Reduction due to Y Direction Earthquake

\begin{tabular}{lccccccc}
\hline EarthquakeLevel & A-B & OL & SLS & DCLS & S & $>$ C & Total \\
Damage Index & 0 & $0-0.1$ & $0.1-0.25$ & $0.25-0.4$ & $0.4-1$ & 1 & \\
\hline Bare Model - EDE & 611 & 473 & 0 & 0 & 0 & 0 & 1084 \\
With Gensui - EDE & 629 & 455 & 0 & 0 & 0 & 0 & 1084 \\
\hline Reduction (\%) & & 3.81 & 0 & 0 & 0 & 0 & \\
\hline Bare Model - MCE & 488 & 395 & 153 & 42 & 2 & 4 & 1084 \\
With Gensui -MCE & 501 & 477 & 105 & 1 & 0 & 0 & 1084 \\
\hline Reduction (\%) & & - & 31.37 & 97.62 & 100 & 100 & \\
\hline
\end{tabular}

Table 6. Drift Ratio based on FEMA 356

\begin{tabular}{|c|c|c|c|c|c|}
\hline \multirow[t]{2}{*}{ Earthquake Level } & \multirow[t]{2}{*}{ Direction } & \multicolumn{4}{|c|}{ Performance Level } \\
\hline & & $\mathrm{OL}$ & $\mathrm{IO}$ & LS & $\mathrm{CP}$ \\
\hline \multirow[t]{2}{*}{ Bare Model-EDE } & $\mathrm{X}$ & & $0.8071 \%$ & & \\
\hline & $\mathrm{Y}$ & & $0.7876 \%$ & & \\
\hline \multirow[t]{2}{*}{ With Gensui - EDE } & $\mathrm{X}$ & & $0.7793 \%$ & & \\
\hline & $\mathrm{Y}$ & & $0.7467 \%$ & & \\
\hline \multirow[t]{2}{*}{ Bare Model - MCE } & $\mathrm{X}$ & & & $1.5195 \%$ & \\
\hline & $\mathrm{Y}$ & & & $1.4617 \%$ & \\
\hline \multirow[t]{2}{*}{ With Gensui - MCE } & $\mathrm{X}$ & & & $1.3844 \%$ & \\
\hline & $\mathrm{Y}$ & & & $1.3142 \%$ & \\
\hline Drift Ratio (\%) & & $0 \%$ & $0-1 \%$ & $1-2 \%$ & $2-4 \%$ \\
\hline
\end{tabular}


Table 7. Beam Damage Index based on ACMC

\begin{tabular}{|c|c|c|c|c|c|c|}
\hline \multirow[t]{2}{*}{ Earthquake Level } & \multirow[t]{2}{*}{ Direction } & \multicolumn{5}{|c|}{ Performance Level } \\
\hline & & $\mathrm{OL}$ & SLS & DCLS & $\mathrm{S}$ & $\mathrm{C}$ \\
\hline \multirow[t]{2}{*}{ Bare Model-EDE } & $\mathrm{X}$ & $\checkmark$ & & & & \\
\hline & $\mathrm{Y}$ & $\checkmark$ & & & & \\
\hline \multirow[t]{2}{*}{ With Gensui - EDE } & $\mathrm{X}$ & $\checkmark$ & & & & \\
\hline & $\mathrm{Y}$ & $\checkmark$ & & & & \\
\hline \multirow[t]{2}{*}{ Bare Model - MCE } & $\mathrm{X}$ & & $\checkmark$ & & & \\
\hline & $\mathrm{Y}$ & & $\checkmark$ & & & \\
\hline \multirow[t]{2}{*}{ With Gensui - MCE } & $\mathrm{X}$ & & $\checkmark$ & & & \\
\hline & $\mathrm{Y}$ & & $\checkmark$ & & & \\
\hline Damage Index & & $<0.10$ & $0.10-0.25$ & $0.25-0.40$ & $0.4-1.0$ & $>1.0$ \\
\hline
\end{tabular}

Table 8. Column Damage Index based on ACMC

\begin{tabular}{|c|c|c|c|c|c|c|}
\hline & \multirow[t]{2}{*}{ Direction } & \multicolumn{5}{|c|}{ Performance Level } \\
\hline & & $\mathrm{OL}$ & SLS & DCLS & $\mathrm{S}$ & $\mathrm{C}$ \\
\hline \multirow[t]{2}{*}{ Bare Model - EDE } & $\mathrm{X}$ & $\checkmark$ & & & & \\
\hline & $\mathrm{Y}$ & $\checkmark$ & & & & \\
\hline \multirow[t]{2}{*}{ With Gensui - EDE } & $\mathrm{X}$ & $\checkmark$ & & & & \\
\hline & $\mathrm{Y}$ & $\checkmark$ & & & & \\
\hline \multirow[t]{2}{*}{ Bare Model - MCE } & $\mathrm{X}$ & & & & & $\checkmark$ \\
\hline & $\mathrm{Y}$ & & & & & $\checkmark$ \\
\hline \multirow[t]{2}{*}{ With Gensui - MCE } & $\mathrm{X}$ & & $\checkmark$ & & & \\
\hline & $\mathrm{Y}$ & & & $\checkmark$ & & \\
\hline Damage Index & & $<0.10$ & $0.10-0.25$ & $0.25-0.40$ & $0.4-1.0$ & $>1.0$ \\
\hline
\end{tabular}

\section{Concluding Remarks}

In its current condition, Building T of Petra Christian University designed using PPTGIUG 1983 can resist elastic design earthquake level (2/3 of MCE) of SNI 1726:2012. However, it does not survive the MCE (2500-year return period). The building performance is greatly enhanced after installation of VSL Gensui damper. The drift ratios and displacements are respectively reduced as much as $4 \%$ and $9 \%$ for elastic design earthquake (EDE) and 9\% and 14\% for maximum considered earthquake (MCE). Some collapses of column can also be prevented. It can be concluded that the building can be retrofitted by using VSL-Gensui damper to meet the seismic performance required by SNI 1726:2012.

\section{References}

1. Lumantarna, B., Pengantar Analisa Dinamis dan Gempa, Lembaga Penelitian dan Pengabdian kepada Masyarakat Universitas Kristen Petra, Surabaya, 2000. (in Indonesian).

2. PPTGIUG 1983, Peraturan Perencanaan Tahan Gempa Indonesia Untuk Gedung, Ditjen Cipta Karya Direktorat Penyelidikan Masalah Bangunan, 1983. (in Indonesian).
3. SNI 1726-2012, Tata Cara Perencanaan Ketahanan Gempa untuk Struktur Bangunan Gedung dan Non Gedung, Badan Standardisasi Nasional, 2012. (In Indonesian).

4. Computers \& Structures, Inc., CSI Analysis Reference Manual, Berkeley, California, USA, 2016.

5. FEMA 356-2000, Pre Standard and Commentary for the Seismic Rehabilitation of Buildings, American Society of Civil Engineers, 2000.

6. ACMC 2001, Asian Concrete Model Code Level 1 \& 2 Documents, International Committee on Concrete Model Code for Asia, 2001.

7. Susanto, A., Non-Linear Time History Seismic Analysis with VSL Gensui Dampers in ETABS, VSL Hongkong Limited, Hongkong, 2011.

8. Khan, W, Akhtar, S., and Hussain, A., NonLinear Time History Analysis of Tall Structure for Seismic Load Using Damper, International Journal of Scientific and Research Publications, 4(1-5), 2014.

9. Montejo, L.A. and Kowalsky, M.J., CUMBIA Set of Codes for the Analysis of Reinforced Concrete Members, North Carolina State University, Raleigh, 2007. 